\title{
Article
}

\section{Issues and challenges in the application of Husserlian phenomenology to the Lived Experience of Hate Crime and Its Legal Aftermath}

Mcguire, Kim and Salter, Michael

Available at http://clok.uclan.ac.uk/10448/

Mcguire, Kim ORCID: 0000-0003-2713-8846 and Salter, Michael (2015) Issues and challenges in the application of Husserlian phenomenology to the Lived Experience of Hate Crime and Its Legal Aftermath. Journal of Interpersonal Violence, 30 (10). pp. 1782-1802. ISSN 0886-2605

It is advisable to refer to the publisher's version if you intend to cite from the work. http://dx.doi.org/10.1177/0886260514548582

For more information about UCLan's research in this area go to http://www.uclan.ac.uk/researchgroups/ and search for <name of research Group>.

For information about Research generally at UCLan please go to http://www.uclan.ac.uk/research/

All outputs in CLoK are protected by Intellectual Property Rights law, including Copyright law. Copyright, IPR and Moral Rights for the works on this site are retained by the individual authors and/or other copyright owners. Terms and conditions for use of this material are defined in the policies page. 


\section{Abstract}

The field of hate crime research addresses the presence, sources and impact of particular types of expressions of prejudice, often perceived as particularly damaging and hurtful forms of interpersonal abuse and violence. Little, if any, credible academic research seeks to vindicate the specific racist, gendered and other vicious prejudices articulated by many perpetrators of hate crime. In turn, this raises the reflexive question of the possibilities of researchers themselves ever being able to adopt a truly "unprejudiced" approach to the presence of such damaging prejudices. Can this goal be realised without a researcher necessarily losing an experientially-grounded understanding of what these meanings, values and purposes have come to mean, and how they are themselves interpretatively re-constituted anew, including within the lived experience of victims, witnesses, police, prosecutors, judges and victim support workers?

A possible philosophically-informed approach to the dilemmas posed by this topic is offered by Husserl's phenomenology. Husserl's perpetually unfinished philosophical methodology strives, with concerted if sometimes tragic reflective rigor, to "suspend," "bracket out" and "neutralise" those core presuppositions constitutive of the research field that typically pre-judge precisely whatever demands to be questioned and explored in a radically non-prejudicial manner. This study critically explores the possibilities, reflective stages and theoretical limitations of a sympathetically reconstructed Husserlian approach to hate crime, itself understood as a would-be qualitative "science of consciousness." It argues that despite its manifest tensions, gaps, ambiguities and internal contradictions, aspects of the Husserlian philosophical approach directed towards the different levels of 
experienced hate crime still retain the potential to both challenge and advance our

understanding of this topic. It is the "instructive" part of "instructive failure" that this article highlights.

\title{
Keywords:
}

Husserl, phenomenology, hate crime as experienced, limits of phenomenology.

'The first thing we must do ... is to take the conscious life completely without prejudice.'

\author{
Edmund Husserl ${ }^{1}$
}

\section{Introduction}

Many scholars and contributors to studies on the criminal justice system have recognised a discrepancy between formalistic doctrinal, law and economics or jurisprudential analysis of a given topic, and evidence of how these topics are actually being subjectively lived, experiencedand interpreted, including by victims of crime, lawyers, judges, victim support workers, and lay persons affected by such criminality. ${ }^{2}$ Sometimes the complaint is that

\footnotetext{
${ }^{1}$ Edmund Husserl, The Crisis of European Sciences and Transcendental Phenomenology, Evanston, Northwestern Univ. Pr. 1970, 233.

2 The phenomenological concept or experience (more precisely experience of the category of experience signifying the self-givenness of objects to express or tacit consciousness) is complex. See Husserl, Experience and Judgment,

Evanston: Northwestern Univ. Press, 1973, 27-28, 331-333; Husserl, Ideas Pertaining to a Pure Phenomenology and to a Phenomenological Philosophy - Second Book: Studies in the Phenomenology of Constitution, 1989. R. Rojcewicz and A. Schuwer, translators. Dordrecht: Kluwer; Husserliana: Phänomenologische Psychologie Vorlesungen Sommersemester 1925 Volume 9 of Husserliana: gesammelte Werke, Archives Husserl à Louvain, Springer 2010; Zur Phanomenologie der Intersubjektivitat: Texte aus dem Nachlass Zweiter Teil, 1921-1928, editor Iso Kern, Springer,
} 
legal analysis, even that of human rights scholarship, is grounded upon an overlay of superimposed premises and specialist modes of discourse. Without good reason, these tend to disregard both the lived-experience of the situation in question, and the lay concerns and social interests that first generated this as a research theme. ${ }^{3}$

We would argue that a Husserlian type of phenomenological analysis, grounded within Husserl's middle and later works, is especially applicable to hate crimes because of its systematic and philosophically informed and rigorous interrogation of the lived experience of such crimes precisely as they are being subjectively encountered. The very term "hate crime” is often deployed in an extremely loose and unreflective manner. That is, as a shorthand term for almost any expression or act to which a discriminatory motivation is being ascribed, and without addressing questions of definition. Given the focus of Husserlian phenomenology on the systematic recovery of unreflectively "lived through" experiences whose meanings are largely taken for granted, a phenomenological approach is particularly useful as a corrective both to the "natural attitude" of everyday life and to other scholarly approaches that gloss over the meanings of such experiential data, or even the data itself. Of course, Husserlian such analysis could and should be applied to other forms of experienced criminality ${ }^{4}$ and subjective encounter with the legal system more

2013.

3 William E. Conklin, 'Human Rights, Language and Law: A Survey of Semiotics and Phenomenology,' 27 Ottawa L. Rev. 129 (1995-1996).

${ }^{4}$ Here we are thinking of the works of R.Meek, 'The experiences of a young Gypsy-Traveller in the transition from custody to community: An interpretative phenomenological analysis’ Legal and Criminological Psychology, Volume 12, Issue 1, pages 133-147, February 2007; Rosie Meek, 'Experiences of Younger Siblings of Young Men in Prison,' Children \& Society, 2008, 22, 4. 5; M.Salter, 'Judicial Responses To Football Hooliganism', Northern Ireland Legal Quarterly, Vol. 37, No.3, Autumn 1986, 280-292; McGruder, Karen Elizabeth. "Some potential contributions of a phenomenological approach to crime." PhD diss., University of New Mexico, 1996; Boeff, Dismas Raymond. "Phenomenological criminology and the Catholic correctional chaplaincy." PhD diss., Sam Houston State University, 1986;D.Matza, Becoming Deviant, Prentice-Hall, Inc., Publishers, Englewood Cliffs, New Jersey, 1969);D.Matza, Delinquency and Drift, ( Transaction Publishers, 1964); Katz, Jack. Seductions of crime: Moral and sensual attractions in doing evil. Basic Books, 1988; Cicourel, Aaron Victor, The social organization of juvenile justice, Transaction Books, 1995. 
generally, ${ }^{5}$ and indeed there is an established literature on phenomenological approaches to state regulation through law in general. ${ }^{6}$ Although a Husserlian account could be applied to other areas of the criminology such as domestic violence and sex crimes, we would argue that this approach is especially insightful for hate crime research given the frequent lack of phenomenological sensibility and rigor - even within qualitative studies that are broadly interpretative. There are forms of academic analysis that re-arrange value-loaded ideas with conceptions that are clearly far removed from the intuited contents of lived experience. Such research develops their critiques from "on high," rather than upon the basis of an insider's firsthand knowledge of the topic itself acquired through ethnographic and/or qualitative research into its presence to the consciousness of participants and affected parties. ${ }^{7}$

In response to these problems, critics have called for the adoption of an expressly experiential, or "phenomenological," approach as a remedy for this discrepancy. ${ }^{8}$ Edmund Husserl, the founder of modern phenomenological theory and research methodology, has argued that, in order for any type of natural or social science to 'begin at all,' that is, before any theorising about specific topics can even occur, a major condition must be fulfilled.

\footnotetext{
5 M.Salter, "Towards A Programme Of Foundational Legal Research", Journal Of The British Society For Phenomenology', (JBSP) Vol. 19, No.2, May 1988, 250-258; M.Salter, 'A Dialectic Despite Itself? Overcoming the Phenomenology of Legal Culture’ S.\& L.S. [Social and Legal Studies, Sage], 1995, 4(4), 453-476.

${ }^{6}$ See four works by Michael Salter and collaborators: 'Towards a Phenomenology of Legal Thinking', Journal Of The British Society For Phenomenology (JBSP) Vol. 23, No.2, 1992, 167-182; 'Common Sense and the Resistance to Legal Theory’, Ratio Juris, Vol. 5, No.2, July 1992: 212-229; ‘On Heidegger's Account of Interpretation’, New Comparisons, No.17 , Spring 1994, 150-169; 'On the Idea of a Legal World', Int 'I Jnl of the Legal Profession, Vol.1, Winter 1994, 283- 310 .

7 This is not to deny that phenomenological analysis itself involves the interpretive activity of structuring research materials, such as firsthand reports, interview transcripts, notes from direct participant observation. It is rather to emphasise the distinction between developing an optimal form of receptivity and responsiveness to qualitative data on the one hand, and the prejudicial force-fitting of such materials into given, fixed and pre-conceived categories on the other, particularly in ways that pre-empt these materials from ever becoming radically questioned, modified or experientially-grounded.

${ }^{8}$ Augusto Balloni, for example, calls for the study of the experience of victims 'in the broadest possible sense of the term.' Augusto Balloni, 'Victims, Crimes, and Social Context,' in Critical Issues in Victimology: International Perspectives, Emilio C. Viano ed., 1992: 17, 22; I. F. Caramazza and U. Leone, Phenomenology of Kidnappings in Sardinia: Towards an International Perspective of a Local Crime Problem, The United Nations Social Defence Research Institute, Rome, Italy: 1984.
} 
Namely, that researchers ought first secure an in-depth qualitative awareness of the particular type of objects and themes that make up the distinctive fields of research in question: one that is grounded in the intuitive evidence of firsthand lived-experience. ${ }^{9}$ It is first necessary, Husserl claimed, to establish the meaning and scope of founding categories. For instance, the meaning and scope of the "juris" of jurisprudence, the "social" of sociology, the "psyche" of psychology, the "physical" of physics, the "life/bio" of biology, the "criminality" of "hate crime," etc. ${ }^{10}$ In other words, to elucidate founding categories that might otherwise remain taken for granted even by expert researchers.

What can it mean to develop a distinctly "experiential-phenomenological" research project into hate crime, drawing upon the philosophy underpinning Husserlian phenomenological theory, and involving a sequence of stages and levels of analysis, each building upon accumulated results of earlier phases? ${ }^{11}$ Provisionally, this can be understood as a type of research programme that clearly shows how it is possible to take seriously and analyse different aspects of the "lived-experience" of hate crime. Here, such experience, saturated with relations of meaning, value and purpose, needs to be treated as a topic demanding attention and close analysis purely in its own right and - as far as possible - on its own terms. ${ }^{12}$ Phenomenology does not analyse, say, the experience of hate crime in

\footnotetext{
${ }^{9}$ Husserl, 1970 op cit, 10-11; 46-53. For the present authors earlier efforts to adapt the philosophy underpinning Husserlian phenomenology to the demands of conducting research on legal topics, see Salter, M., 'On The Beginnings of Foundational Legal Research Into Legal Discourse,' Liverpool Law Review, Vol. 9, No.1, April 1987, 23-43; Salter, M., 'Towards a Programme of Foundational Legal Research," Journal of the British Society For Phenomenology,' Vol. 19, No.2, May 1988, 250-258.

10 Husserl's work Experience and Judgment, Northwestern Univ Press, Evanston, 1973 also provides a most useful basis for developing and refining a distinctly experiential approach to law.

${ }^{11}$ Husserl, The Idea of Phenomenology, Nijhoff, The Hague, 1964, 10. Phenomenology, as a philosophical-theoretic methodology, was established by Edmund Husserl (1859-1938), and his approach, as extended by his successor, Martin Heidegger (1889-1976), was extremely influential within continental Europe during the 20th century, especially Germany. It's influence was extended into postwar France by Simone Goyard-Fabre, Paul Amselek (1937-- ), and Jean-Louis Gardies (1905-), but without making any comparable impact within the English-speaking world. Its take up within Anglo-American legal studies has been patchy.

12 Husserl, 1970 op cit, 125-6. Again such immersion and submission to the lessons exhibited by qualitative data does not deny either a relation of dialogue between the researcher's own interpretive framework and the research topic, or the
} 
a manner that presupposes an already given type of "solution" or policy response (based, e.g., on free-market or socialist ideological premises) to which the researcher was already committed from the start. Hence, its policy-oriented practical implications stem from a process of discovery, not the self-fulfilling vindication of the researcher's own superimposed prejudices.

In terms of traditional theoretical oppositions and distinctions, such experiential research has to be qualitative and interpretative in nature, as opposed to quantitative and positivist-causal. ${ }^{13}$ That is, it makes no effort to generate and analyse official statistical data to provide a "causal explanation" of hate crime incidents reinterpreted in naturalistic terms of "behaviour," and in relation to, say, changing levels and distributions of unemployment, social deprivation or other alleged "social variables" taken as "causes" of different patterns of hate crime. ${ }^{14}$ Nor does it rely upon the premises of either deductive or inductive logic, and thus: 'does not theorise or carry out mathematical operations; that is to say; it does not carry through any explanations in the sense of deductive theory.' ${ }^{15}$

Husserlian phenomenology thus opposes a "naturalistic" approach to hate crime for which this topic is treated simply as part of material nature, a concept that subsumes even the conscious life of those involved or affected by this activity. ${ }^{16}$ When interpreted in a naturalistic manner, hate crime would have to be analysed by means of natural-scientific methods, including a materialist form of psychology or sociology, oriented toward given

\footnotetext{
selectivity involved in questioning, selecting and interpreting it - a point tackled later in this paper.

13 Husserl, Ideas, W.R. Boyce Gibson trans., 1982, 33-51, 135-7; Husserl, 1970 op cit, 135-7, 215-19.

${ }^{14}$ Husserl, 1970 op cit, 221-24; Husserl, 1964 op cit, 4-5, 20-21, 46. The fact that deep seated assumptions have been given statistical form, and can thereby be expressed with exactitude and through statistics, graphs, charts etc., does not prevent them from being problematic for Husserl.

${ }^{15}$ Husserl, 1964 op cit, 5, 16.

16 Husserl, 1970 op cit, 5-11, part 2.
} 
empirical facts and causal explanations of relevant factual situations. ${ }^{17}$ Whilst expressly phenomenological studies of hate crime are rare indeed, it is arguably that existing research includes a mixture of qualitative and quantitative approaches. Hence the Husserlian critique is more directly relevant only to that sub-set of positivistic, causal studies that rely naively upon official statistics as expressing "hard data." However, the level of methodological reflection and rigor displayed by the existing qualitative studies could, we suggest, still be substantially upgraded through a critical engagement with Husserlian phenomenology.

In addition to faithfully investigating and describing particular experiences of affected parties in their distinctiveness, meaningfulness and diversity, ${ }^{18}$ a Husserlian phenomenological approach also analyses a number of those core structures, general patterns and principles that can be found within, or - as deep-seated structures - underlie, such experiences. ${ }^{19}$ These typically govern their "appearance" within the experiential realm in various interesting ways. ${ }^{20}$ Here, we can, following Husserl, take a factual scenario that has already been successfully prosecuted under UK legislation as a "disability-related hate crime,” and then ask the following analytical questions: Which of its features appears to be operating as "essential preconditions" for its identification and legal interpretation as a hate crime of this particular sub-category and a "hate crime" more generally. Secondly, which of the experienced qualities of this instance of a disability-related hate crime appear to be "optional," such that their absence in any particular reported case would not have affected this classification in either one way or the

\footnotetext{
17 Husserl, 1970 op cit, 61-67, 211-13.

18 Husserl, 1973 op cit, 253, 264-71.

19 Husserl, 1973 op cit, 339-348; Husserl, 1964 op cit, 6-7.

20 Husserl, 1982 op cit, 156-64; Husserl, 1964 op cit, 41-2.
} 
other. For example, the hair colour, height and age or gender of the victim in question. And, finally, what other potential features had they been identified as present would have undermined the very possibility of this interpretive classification? For example, if an assault occurred on someone with a hidden disability not apparent to the perpetrator. Would the absence of perceived disability transform what could be identified as "a disability related hate crime " into merely a "simple assault" for example? ${ }^{21}$ Equally, perception of low-level' targeted harassment as anti-social behaviour, rather than targeted 'hate crime' transforms the recording and prosecution of a crime.

Categories define what can be 'seen' as a hate crime. Gender-bias is a 'hate crime' in twenty- seven US states, ${ }^{22}$ but not in the UK. Therefore, crimes expressly committed because of bias against, for example, females, in the UK, will not be classified as 'hate crimes'. The case of Levi Bellfield is indicative: according to police and media reports Levi'... spoke of 'hatred' and 'intense loathing' of women; a former girlfriend described how he had confessed that he would wait in alleyways wanting to: "hurt, kill, stab or rape women.” 23 Long argues,'... if Bellfield's hate-motivated violence had been directed at victims on the basis of their perceived race, religion or belief, sexual orientation, disability or transgender identity, his crimes would clearly have been recognised as hate crimes. ${ }^{24}$ For Husserl, this structural type of analysis is only possible once the more descriptive phase of experiential research has been completed. He termed it "eidetic analysis" - from

\footnotetext{
${ }^{21}$ Husserl, 1982 op cit, 8-14.

22 For empirical studies into reasons for and against the inclusion of gender in US : McPhail. B.A. \& DiNitto. D.M, 'Prosecutorial perspectives on gender-bias hate crimes' [2005] Violence Against Women, 11(9), 1162-1185: Hodge, 2011 op.cit.

${ }^{23}$ See Julia Long 30 November 2010

http://www.opendemocracy.net/5050/julia-long/should-violence-against-women-in-the-uk-be-seen-as-hate-crime accessed 18/2/13. Bellfield was convicted of murdering 3 females, and of 'attempted murder' of another. 24 Ibid.
} 
"eidos" or "essence." ${ }^{25}$ It is a research method that can be used when answering each of the four main questions that comprise an overall phenomenological approach to any topic, and which are discussed in detail by the following subsections.

\section{Four Main Questions}

There are four main research questions posed by a Husserlian phenomenological approach concerned with the basic structures of lived experience. The first questions the very starting position and aims of its own experiential research, partly by seeking to set aside more conventional positivist premises that are linked to the philosophy of materialism and materialistic "explanations." ${ }^{26}$ Husserlian analysis asks: by means of which cluster, or sequence, of research methods is it possible to gain appropriate access to the lived experience of hate crime sufficient to overcome the difficulties that bedevil more conventional ways of conducting research into hate crime? Here, we could point to phenomenological methods of ethnographic research and participant observation involving the researcher's immersion in the experiential "life worlds" of those involved in, or affected in various ways by, hate crime or engaged in implementing law-related institutional responses to such criminality. Other less direct methods include focus groups, and semi-structured interviews with such participants designed to uncover relevant lived experiences and how these are being routinely interpreted. ${ }^{27}$

Must researchers uncritically adopt and apply stereotypes, forming part of taken for

\footnotetext{
${ }^{25}$ Husserl, 1973 op cit, 337ff.

${ }^{26}$ Husserl, 1970 op cit, 65-68.

27 A qualitative phenomenological methodology has been developed by the "Duquesne School” of The Descriptive Phenomenological Method in Psychology), including by Amedeo Giorgi and Frederick Wertz. See Giorgi, Amedeo (2009), The Descriptive Phenomenological Method in Psychology. Duquesne University Press: Pittsburgh, PA; an d Wertz, F. J. (2005). 'Phenomenological research methods for counseling psychology,' Journal of Counseling Psychology, 52(2), 167-177
} 
granted interpretations or official policy assumptions and statistics, as their starting point? ${ }^{28}$ Alternatively, do they as Husserl insists, need - as far as humanly possible, and subject to limitations clarified during later stages of phenomenological analysis, to actively suspend (or "neutralise," "disengage" and "bracket out") these assumption-rich starting points in order to begin experientially-grounded research? ${ }^{29}$ Is such an optimal possible, if necessarily incomplete, suspension of presuppositions needed to allow a more complete and less distorted understanding of the topic to gradually emerge? ${ }^{30}$

Phenomenology is critical in that its opening methodological devices strives as far as humanly possible to suspend and neutralise whatever is ideologically taken for granted about hate crime, and whatever constitutes an "appropriate" policy response to it. In practice, only an approximation of complete suspension will ever be possible. ${ }^{31}$ Instead of simply accepting a given meaning and its presupposed validity as intrinsic to the given transcendent nature of hate crime as such, to its sheer matter-of-fact "thatness," phenomenological methodology places the validity of these meanings into question; it does so to better establish an experientially-grounded interpretation. ${ }^{32}$ There is the demand not to be deceived by taking interpretations founded upon traditional assumptions "on trust," and, therefore, to treat as claims to knowledge what conventionally pass as "obvious"

\footnotetext{
${ }^{28}$ Alfred Schutz, "Common-sense and Scientific Interpretation in Human Action." In Philosophy and Phenomenological Research. (1953).14: 1-38; and Alfred Schutz, "Type and Eidos in Husserl's Late Philosophy." In Philosophy and Phenomenological Research. (1959) 20: 147-165. Schultz's category of typification implies that stereotyping is a sub-set of a more general process of viewing particular topics of experience through general categories or types, but that not all typication involves the negative connotation of unreflective and stereotyping of the kind common to hate speech and hate crime.

${ }^{29}$ Husserl, 1982 op cit, 5-7, 51-60, 63-7.

30 Husserl, 1973 op cit, 41-47; Husserl, 1970 op cit, 233. Here, there is also a need to acknowledge the limitations of this effort of purging of prejudice, and open acknowledgment that the subjectivity and orientation of phenomenological researchers is also in continual process of construction/reconstruction in various phenomenologically interesting ways soon to be discussed, albeit one that tries to take its clue from the topic.

31 Richard Zaner, The Way of Phenomenology: Criticism as a Philosophical Discipline, New York, 1970 46-8; John O’Neil, 'Can phenomenology be critical?' 2 Philosophy of the Social Sciences 1972: 1-13, 1. This essay is also contained in in Thomas Luckman, ed., Phenomenology and Sociology, Penguin, 1968.

32 Husserl, 1964 op cit, 38-9.
} 
common sense knowledge. ${ }^{33}$ The wider goal is to break free of the deep moorings of routine acceptance the status quo as a matter of course, in which whatever exists is taken for granted precisely because "that is the way it is," or "that's life" or other dubious rationalisation such as "human nature."

Indeed, deploying unambiguous language, Husserl himself insisted that: 'the task ... is, first of all, a critical one. ${ }^{34}$ For him, critical analysis is not merely one among many other characteristics and goals of phenomenological research, whose adoption or rejection is strictly optional. On the contrary, if phenomenological research were ever to abandon its critical and questioning stance, its treating as problematic that which is being ideologically promoted as self-evidently true, then it would be left with 'no sensible objectives' whatsoever. ${ }^{35}$ Even at the very start of concrete research, a phenomenological critique is necessary to "loosen up" elements of complacency of a self-evident and all-too easily self-satisfied cultural traditions shaped decisively by the presuppositions of naive realism, naturalism and positivism. The challenge here is to both dissolve and reconnect this tradition's basic concepts with the original, or "raw," pre-linguistic experiences and experiential structures from which they originate, but which have become buried. ${ }^{36}$

Should researchers seek to answer "why-type" questions that supposedly explain (or perhaps more critically "explain away") this topic in a manner using a "cause and effect" model of analysis rooted in a certain $19^{\text {th }}$ and early $20^{\text {th }}$ Century model of natural science? If not, as phenomenologists insist for various interesting reasons, should we adopt an

\footnotetext{
33 Husserl, 1964 op cit, 4.

34 Husserl, 1964 op cit, 17.

35 Husserl 1964, 2.

36 Heidegger, M., Being and Time, NY: State University of New York Press; Revised edition 2010, para. 6. This is, I would emphasise, is a reference to realties as concretely lived and experienced in terms of their what and how, not to transcendent, extra-experiential realities per se.
} 
approach that is more expressly interpretative and qualitative in nature ${ }^{37}$ If so, then what does this methodological and philosophical commitment actually mean in practice for conducting an applied project on the lived experience of hate crime? Is a strictly qualitative "explanation" of hate crime a contradiction in terms? Or, does adopting Husserl's phenomenological approach to the conduct of research on this topic demand a different and distinctly interpretative-hermeneutical type of "explanation": an explanation where one's consciousness of hate crime as something experienced is accounted for in terms of the ("transcendental") sense-making dynamics and activities of consciousness itself. ${ }^{38}$ These include the interests, concerns and orientations of different individuals and wider communities of interpreters located within various intersubjective "life-worlds?" 39 If so, then is the idea of a "science of consciousness of phenomena," or phenomeno-logy, able to demonstrate, contrary to a range of theoretical objections, that it remains a viable project? To answer these methodological questions requires us to clarify a series of levels of analysis, each of which poses a distinct type of questions asked in a necessary sequence: what-type, how-type and for-whom type questions.

In terms of qualitative content, or "sense," Husserlian phenomenology asks the what-question: i.e., what is it that is being commonly experienced as a "hate crime" both generally and in terms of specific subcategories or "types"? ${ }^{40}$ In opposition to all naturalistic approaches, this level of phenomenological analysis of hate crime turns directly to the evidence of lived experience of this topic. It describing and elucidates how this

\footnotetext{
37 Husserl, 1970 op cit, 230-32.

38 Husserl, 1964 op cit, 35: This is an explanation of basic concepts and propositions which function as principles governing the possibility of all conceivable scientific and other interpretations and explanations of hate crime, together - at a later stage - with a similar type of explanation of phenomenology's own categories and principles, including qualitative forms of explanation. Ibid, 46.

${ }^{39}$ Husserl, 1973 op cit, 41-52; Husserl, 1970 op cit, 48-53, 121-132. For a transposition and application of the concept of life-world into the specifically legal sub-sphere of society, see Salter, M., 'On the Idea of a Legal World', Int'l Jnl of the Legal Profession, Vol.1, Winter 1994, 283- 310.

${ }^{40}$ Husserl, 1970 op cit, 241.
} 
"takes shape" within the first person subjective life of those who have different types of involvement and engagement with this phenomenon. ${ }^{41}$ Phenomenology thereby takes advantage of the fact that consciousness is, by its very nature, potentially open to aspects of itself through inwardly directed acts of reflection that seize upon and grasp the streaming flux of its own interpretative acts and their contents. ${ }^{42}$ In place of causal-naturalistic "explanations," a phenomenology of hate crime provides richly descriptive elucidations of the interconnectedness and correlation of processes of "experiencing" and whatever is being subjectively experienced and interpreted $a$ a hate crime, or as a hate incident. In other words, the focus of this type of research falls upon the best ways of gaining access to, and then faithfully describing, clarifying and distinguishing, the meaning that being involved in a hate crime incident can and does exhibit for affected and involved parties. ${ }^{43}$ As Husserl notes: 'Phenomenology proceeds by "seeing," clarifying, and determining meaning, and distinguishing meanings. It compares, it distinguishes, it forms connections, it puts into relation, divides into parts, or divides abstract aspects. ${ }^{.44}$ As important, such elucidation and analysis can succeed in uncovering interpretive conditions of the possibility of such experience. ${ }^{45}$

The overall goal of such qualitative phenomenological research at this what-level is to make the "phenomena" of hate crime, that is, the presence of this topic to the consciousness of different individuals who experience and interpret it as something meant, as intelligible as possible. The same point applies to the relationship within the overall research field

\footnotetext{
41 Husserl, 1964 op cit, 10.

42 Husserl, 1982 op cit, 78-80; Husserl, 1964 op cit, 1. This is not to deny the role of external validation by others, but only to insist that, without such potential openness to sustained self-reflection, phenomenological analysis would be impossible.

43 Husserl, 1982 op cit, 151-6; See

http://www.equalityhumanrights.com/uploaded_files/research/disabled_people_s_experiences_of_targeted_violence_an d_hostility.pdf

${ }^{44}$ Husserl, 1964 op cit, 46.

45 Ibid. Husserl, 1964 op cit, 1.
} 
between the central topic and other related themes. ${ }^{46}$ This involves making a concerted effort to enhance our understanding of the far-reaching impact and ramifications of such criminality on those directly and indirectly involved and affected by their experience of it. This includes witnesses, as well as officials charged with responding to reported incidents, and others involved with specifically legal and policy dimensions of this issue, such as legislators, judges, prosecutors and police officers.

Ideally, but subject to practical limitations addressed below, the what-question is posed from the perspective of a 'fully "disinterested" spectator' whose purely cognitive interest lies in securing whatever answer to issues concerning hate crime best fits the available experiential evidence. ${ }^{47}$ The goal is to gain access, describe and elucidate consciousness of this topic just as it immediately presents itself, as itself, to be. ${ }^{48}$ Taken purely as given perceptually, what meanings are being routinely ascribed to hate incidents within the everyday life-worlds of affected parties and those who have official responsibilities for responding to such incidents? ${ }^{49}$ Here, legal definitions contained in both statutes but also within case law decisions need to be identified, distinguished and analysed in terms of their meaning, scope and rationale.

However, from a phenomenological standpoint, such "official understandings" operating from the "top down" as were - also need to be counterbalanced by the interpretations of others working at the grassroots level of everyday life, including victims, witnesses and perpetrators of hate crimes. ${ }^{50}$ In this way, Husserlian analysis also operates from the "bottom up," as it were, viewing officially defined and interpreted realities related

\footnotetext{
46 Husserl, 1964 op cit, 37.

47 Husserl, 1970 op cit, 157.

48 Husserl, 1970 op cit, 233. In other words, the topic is consciousness of hate crime, the appearance and manifestation of such crime purely within lived experience and as the object of an activity of different modes of experiencing it.

49 Husserl, 1970 op cit, 172.

${ }^{50}$ In one qualified sense, this list ought to include the experiences of researchers ourselves.
} 
to hate crime incidents from the perspective of everyday life as lived and experienced from the "ground up" as element of subjective and intersubjective "life-worlds." ${ }^{51}$ This requires securing many first-hand accounts of hate crime, and then elucidating both their distinctive, as well as shared qualities, including implicit as well as explicit elements of their lived significance. Here, the task is to elucidate what is given in the sense intuition of affected parties purely as it has been experienced as something meant without researchers superimposing prejudicial additions, subtractions or overlays of reinterpretation upon the topic itself. ${ }^{52}$ The concern is purely with the "whatness" of the lived experience in question, whilst remaining strictly agnostic concerning judgments about the "thatness" of whatever is being experienced (i.e., hate crime's extra-experiential presence and causes). ${ }^{53}$ These actor accounts expressing interpretative understandings take shape as parts of a subjective-relative world in which the total communal life of efforts, concerns and accomplishments are realised through social action. ${ }^{54}$ Having been identified and their sense elucidated, their "whatness" as it were, these understandings of meaning, value and purpose, then need to be placed under a nexus of various sub-headings and headings devised to bring out the rich diversity of these experiences.

Experienced meanings, values and purposes are subject to a detailed elucidation and clarification of their sense-contents, their "whatness," to the point where these become increasingly distinct and optimally determinate. The distinctive character of meanings themselves, their form as ideal and immanent cultural entities exempted from natural qualities and vulnerabilities, such as physical destruction and burning, also becomes

\footnotetext{
51 Husserl, 1973 op cit, 24-28.

52 Husserl, 1970 op cit, 157-59, 235-6.

53 Husserl, 1970 op cit, 157-59, 235-8; Husserl 1982 op cit, 51-60.

${ }^{54}$ Husserl, 1970 op cit, 157.
} 
increasingly apparent. ${ }^{55}$ So too does the differences between the interpretation of the meaning of hate incidents and the transcendent quality of these real incidents themselves. ${ }^{56}$ At this point, further distinctions also become clearer, including in relation to the distinction between the ideal-cultural nature of meanings and whatever is genuinely "internal" to the contents of the streaming flux of interpretative acts of perception, recollection etc. $^{57}$

The next theme, which presupposes the previous phase, is to address the specific manner of appearance of experienced hate crime, the multiplicities of modes of appearing and their interpretive structures, or "ways of being-directed-towards" this topic (understood technically as instances of "intentionality"). ${ }^{58}$ Which modalities can we identify within the above descriptions of lived experience concerning the different "manners of appearance" of a given sense of hate crime? For example, the experience of a single episode can be variously interpreted by different parties called upon to interpret it for legal purposes as "definitively" a hate crime incident, or as a "probable", "possible" or "doubtful" incident of this kind. ${ }^{59}$ In turn, this interpretative dimension can change in the light of new evidence for example, or when interpreters "share notes" as it were, including perhaps a later disclosure of the attackers extensive prior criminal record for racist attacks. $^{60}$

Following on from the above methodological phases addressing already constituted qualitative understandings of the meaning of hate crime together with their manner of subjective appearance, it is important to graduate from this what-level by asking "how

55 Husserl, 1970 op cit, 241-2; Husserl, 1982 op cit, 213-16, 240-43.

${ }^{56}$ Husserl, 1982 op cit, 5-7, 217-221.

57 Husserl, 1982 op cit, 5-7, 217-221, 226-33, 236-240.

58 Husserl, 1970 op cit, 171, 238, 241; Husserl, 1964 op cit, 43.

59 Husserl, 1973 op cit, 87-99; Husserl, 1982 op cit, 249-56.

${ }^{60}$ Husserl, 1964 op cit, 36. 
questions." ${ }^{61}$ Everything that is experienced as this type of criminality is encountered through a certain "mode of appearance," as something perceived, as recalled, anticipated, expressed etc. ${ }^{62}$ For Husserl, there is an essential correlation between what is perceived as hate crime and the interpretative act of perceiving it as such, and this correlation applies to other categories of interpretative act. ${ }^{63}$

The "whatness" of sense of real incidents "takes shape" within lived experience only within, and by means of, the ongoing performances of a certain modes of "interpretative act" and combination of these acts working in concert within the streaming inner flow of tacit and express consciousness. ${ }^{64}$ Everything experienced as part of a hate incident is thus encountered as an index of a subjective system of correlations for which it serves as a clue. ${ }^{65}$ For every perceived and recalled hate incident held to be subjectively valid and real, there is an underlying interpretative act of perceiving and recollection functioning as its correlate, and the same is true for acts of anticipation, imagination, judgment and linguistic expression. ${ }^{66}$ These concern the different underlying interpretative acts that, through an ongoing temporal synthesis, "put together" such established meanings, including hate crimes as perceived (presenting themselves and appearing through the mode of acts of perception), hate crimes as anticipated, as imagined, recalled and as expressed in words. ${ }^{67}$ Phenomenological analysis asks: from what interpretative factors are the ready-constituted meanings of hate crime built up, sustained and modified over time? What possibilities or combinations can be identified within their lived experience, and what

\footnotetext{
61 Husserl, 1970 op cit, 143-8, 152-4.

62 Husserl, 1982 op cit, 5-7, 69-85.

63 Husserl, 1964 op cit, 8.

64 Husserl, 1964 op cit, 11; Husserl, 1970 op cit, 157; Husserl, 1982 op cit, 128-31.

65 Husserl, 1970 op cit, 165-66; Husserl, 1982 op cit, 203-7; Husserl, 1964 op cit, 8-10.

66 Husserl, 1970 op cit, 159-61.

67 Husserl, 1982 op cit, 5-7, 86-92, 100-105.
} 
'geneal interrelations' are being exhibited? ${ }^{68}$

Each type of interpretive act has the common structure of consciousness-of, that is, a relation of "reference" to a cultural or material object or topic, which is meant by it in a characteristic way. ${ }^{69}$ In other words, by virtue of performing interpretative acts, those who experience hate crime encounter an incident as something both "meant" and "actual." This is because consciousness combines consciousness of it (a reference beyond itself towards its targeted object or theme) and a relation to the object as something meant (given sense to by means of interpretive work). ${ }^{70}$ Each type of act has its own characteristic way of progressively constituting an interpretation of hate crime, and fulfilling its possibilities. ${ }^{71}$

At this deeper level of qualitative analysis, we address the question: how do each of these different types of interpretative act operate to "synthesise" (or "constitute") the overall sense of an actual or possible hate crime incident in different characteristic ways? ${ }^{72}$ Typically, most experiences of hate crime are constituted in their meaningfulness through a combination of two or more interpretive acts (or "interpretive performances") acting as sources of cognition, including acts of perception, recollection, anticipation, judgment and expression. For instance, perception is typically mediated on either side of its temporal "here and now" by aspects of recollection, cultural associations and the expectations generated by anticipations. ${ }^{73}$ It is possible to identify relations of dependency and priority between these acts, such as between hate crime as recalled and as originally perceived with intuitive richness of content.

\footnotetext{
${ }^{68}$ Husserl, 1964 op cit, 43.

69 Husserl, 1964 op cit, 15.

${ }^{70}$ Husserl, 1982 op cit, 73-4; Husserl, 1964 op cit, 43.

71 Husserl, 1964 op cit, 11. The role of factors other than interpretative acts of consciousness in constituting the meaning of hate crime, such as bodily sensations, also needs to be acknowledged, although Husserl's published works failed to integrate this dimension, which he recognised as vital, even primordial, into his distinctive methodological discussions.

${ }^{72}$ Husserl, 1970 op cit, 157.

${ }^{73}$ Husserl, 1982 op cit, 145, 164.
} 
On reflection, it is clear that an eyewitness' experience of hate crime generated through her interpretative acts of perception, then followed by her recollection of these experiences to the police and court, is distinctive. It is different in kind from that of those whose experience stems only from reading about it, including her trial testimony, but without benefiting from the contribution of the intuitive richness characteristic of first-hand experiences. ${ }^{74}$ A victim's original perception may also be supplemented by "intrusive" or "unwelcome" recollections, imaginings, anticipations and expressions, each of which, through a process of synthesis, sustain the presence and significance of the attack within the conscious life of that person as its "legacy." At this "constitutive" level, which "explains" the topic in a distinct qualitative sense of this term as the outcome of an interpretative sense-constituting performance, ${ }^{75}$ researchers need to identify and analyse the characteristic contributions made by each of these interpretative acts operating both singularly and in their various combinations. In this way, we address and seek to answer the following question: how is it possible for specific and particular experiences to be interpreted as those of hate crime and for this interpretation to arise, take shape, persist and fade away within the conscious life of different affected or involved parties? ${ }^{76}$

In addition to posing and answering what-type and how-type questions strictly from within the realm of lived experience, we also need to ask "for whom" is there hate crime? ${ }^{77}$ Even the most passive and unwanted perception of a hate crime incident arising through sheer force of association still involves elements of active interpretation. In turn, these appear within the lived experience itself to be the performance of an "interpreter," an

\footnotetext{
74 Husserl, 1973 op cit, 64-71.

${ }^{75}$ Husserl, 1970 op cit, 167-70.

76 Husserl, 1973 op cit, 143, 246; Husserl 1970 op cit, 157-8.

77 Husserl, 1964 op cit, 35.
} 
ego-subject for whom this incident "takes shape" as exhibiting this or that meaning. ${ }^{78}$ The ongoing interpretative constitution of the inward-facing ego-pole of lived experience merits detailed and far reaching phenomenological analysis just much as the outward-facing object-pole of such experience. ${ }^{79}$

Here, hate crime researchers can experience the paradox of encountering a type of subjectivity which is both a "subject-for" the world around itself, as well as experiencing itself as an object for self and others "within" that same surrounding world. ${ }^{80}$ How does the persisting "subject" of lived experience "take shape" within such experience as something (or more precisely "someone") constantly being "synthesised" at the spatial, cognitive and emotional "centre" of such experience, as both its recipient and interpreter? ${ }^{81}$ For everything held to be valid about hate crime, there is the implicit experience of a interpreting subjectivity as the one who is judging and holding it to be valid in a certain way, subject perhaps to various qualifications and provisos. ${ }^{82}$ What is the role of cognitive and extra-cognitive interests in both shaping and motivating the selective attention, perception and perceptual meaning originally given to hate incidents? How is possible for two witnesses occupying an identical physical vantage point to experience "the same" incident in quite different ways ${ }^{83}$ How does a "sense of self" arise, persist, change and fade away within the field of lived experience, whilst the ego itself endures at the centre of the flux of such self-experience? ${ }^{84}$ What is the nature of that 'peculiar temporalisation' by which we become enduring egos reconstituting ourselves anew within our modalities of

\footnotetext{
${ }^{78}$ Husserl, 1970 op cit, 170-71; Husserl, 1973 op cit, 47, 57-8, 209-10, 428-9.

${ }^{79}$ Husserl, 1970 op cit, 171.

${ }^{80}$ Husserl, 1970 op cit, 178-186.

81 Husserl, 1973 op cit, 162-167, 175-77.

82 Husserl, 1970 op cit, 171; Husserl 1982 op cit, 190-92.

83 Husserl, 1970 op cit, 171; Husserl, 1973 op cit, 76-87; Husserl, 1982 op cit, 222-26.

${ }^{84}$ Husserl, 1973 op cit, 293-8.
} 
time? ${ }^{85}$

By reflecting upon the depths of experience at the ego-pole, it becomes possible to identify and unveil which underlying forms of subjective "orientation," position-taking, and "being interested" and "concerned with" this topic are actually in play. ${ }^{86}$ Here, a phenomenology of hate crime needs to ask: How does reflection upon these hidden dimensions help reveal aspects of "who we now have become" whenever we interpret this topic, which highlight the interpretively reconstructed nature of such subjectivity? What role does the continuity of retention of perceptions within memory and their selective reactivation play in the performance of the experienced ongoing unity of the living "subject" of hate crime experience accomplished through interpretive synthesis of its own appearances? ${ }^{87}$ How is it possible for hate crime victims to remain persistently or episodically "in contact" through dialogue with traumatic aspects of the original past incident, perhaps over many years? ${ }^{88}$ On the other hand, victim support agencies may seek to effect a cognitive change moving beyond stereotypical notions of "victim" at least in how people interpret the past and to break any continually connection with a traumatic past. Again, how is this reinterpretation itself possible? How does the subject supply the "centred" quality of lived experience as that an identifiable and self-identical "person" exhibited over ever-changing phases of "one's own" life experience?

Furthermore, there is the question of whether such phenomenological self-reflection can highlight our typically latent value-judgments, habitual patterns of interpretation and thought, deep-seated prejudices and ideological position-takings of various kinds. These

\footnotetext{
${ }^{85}$ Husserl, 1970 op cit, 172.

${ }^{86}$ Husserl, 1973 op cit, 85-87.

87 Husserl, 1970 op cit, 171.

${ }^{88}$ Husserl, 1970 op cit, 172.
} 
include those stemming from our immersion in the various linguistically carried and transmitted cultural traditions and subcultures of modern society? ${ }^{89}$ In turn, this question points to the always already intersubjective character of individual subjectivity: the interconnected quality of individual, group and social "worlds" and common sub-worlds of culture, together with ongoing cultural traditions to which all individuals variously belong. It also highlights the constant and mutual "taking shape" of specific others to whom both individual and group identities are routinely ascribed. This represents an interpretive process exhibiting particular significance for discriminatory abuse and violence based upon such perceived "group identities." ${ }^{90}$

The institutionally coordinated and regulated interpretative performances and expressions of victims, police, prosecutors and judges re-constitute not only personal but also communal worlds existing as much "for us" as "for me alone." ${ }^{91}$ These shared "life-worlds" take shape and are both sustained and modified as correlations for intersubjective syntheses of various kinds performed on the basis of broadly shared orientations of interest, concern and values. Self-experience is mediated by a range of historically established group categories, including families, ethnicities and - at the most general level - that of humanity itself. ${ }^{92}$

In short, after a clarification of various methodological stage and their rationale, it is necessary for the study of hate crime to address four questions concerning the what, manner of appearance, how and for-whom dimensions of lived experience. Each of these levels of analysis must be followed through one at a time within an ever-deepening

\footnotetext{
${ }^{89}$ Harris, C., Salter, M., ‘On Heidegger's Account of Interpretation’, New Comparisons, No.17, Spring 1994, 150-169.

90 Husserl, 1970 op cit, 184-86.

91 Husserl, 1970 op cit, 172.

92 Husserl, 1970 op cit, 172.
} 
movement of analysis. ${ }^{93}$

Each of these distinct analytic parts also needs to address both a methodological and an applied / substantive element. In other words, the question of what is being experienced by respondents as a hate crime first needs to be discussed in general methodological terms of how best to formulate appropriate research techniques and questions sufficient, at least in principle, to provide optimally satisfying answers to this rich question. This needs to be followed by the practical application of these research techniques and modes of questioning, resulting in a descriptive analysis of concrete experiences of hate crime. These include quotations from a variety of primary sources, such as self-reports from victims, witnesses and perpetrators.

That sequence of setting out an initial and generalised methodological discussion, followed by its practical application leading to a substantive analysis of specific experiential data, also needs to be followed by each phase of phenomenological analysis of hate crime. Neither methodological discussion, nor applied research, can be development fruitfully in isolation from each other. All forms of research, even the most "applied" type, rely upon various methodological and philosophical, assumptions. This holds good irrespective of whether researchers are aware of these dependencies, or whether they acknowledge the underlying premises and taken for granted assumptions that first enable their work to proceed as it does. ${ }^{94}$ Hence, there is, I would suggest, an ethical obligation upon researchers to make as "full disclosure" as possible of their underlying methodological commitments and guiding presuppositions. This is important to show that they are aware of not only the latter's theoretical rationale and contextual appropriateness,

\footnotetext{
93 Husserl, 1970 op cit, 171-2.

${ }^{94}$ Husserl, 1982 op cit, 147-49, 181-90.
} 
but also their limitations both generally and with respect to the particular topic.

The upshot of these points concerning the lack of independent self-sufficiency exhibited by both methodological discussion and the application of research is that there is a need to move between these two levels in a zig-zagging fashion, such that the findings attained at each level helps further develop aspects of the other's agenda. In addition, there is a need, at the end of each level of analysis, to set out a self-critical conclusion "summing up" both what has been achieved to date in terms of clarification of hate crimes as lived, and highlighting the still-unfinished business reserved to later stages of phenomenological analysis of experience.

\section{Conclusion}

In brief, I would suggest that, as far as a phenomenology of hate crime is concerned, the main methodological requirement is for the refinement of an approach to the conduct of research that does optimal justice to how this topic is being concretely lived and experienced as part of the furniture of our everyday lives. Researchers need a way of conducting inquiry that takes such experience and its core structures seriously as a topic for analysis in its own right. We need research methods enabling us to describe and unfold the following: the intuited contents of such lived-experience; the dynamics involved in its underlying interpretive processes; their basic or essential structures; and, finally, the role of what appears to be "subjectivities" within such processes. ${ }^{95}$

Hate crime involves discriminatory practices founded on often-unreflective prejudices directed against groups in general. Husserl was especially clear that what lies at the heart of phenomenological research is a critical analysis questioning those instances of unreflective

${ }^{95}$ Husserl, 1964 op cit, 17-18. 
prejudice and deep-seated presuppositions that pass themselves off as received and self-evident wisdom, as what is somehow "obvious" about various minorities. ${ }^{96}$ Indeed, as phenomenological analysis advances through its various stages, there is a continuing and deepening refusal to accept anything about hate crime unexamined as "already given" and simply taken for granted, which has yet to demonstrate its validity experientially. ${ }^{97}$ In turn, this requires a "back and forth" critical movement between, say, theoretical or official "claims" about hate crime contrasted with evidence derived from an adequate interpretation of how this topic manifests itself experientially within different forms of life or "ego-comportments." ${ }^{98}$ The very aspiration to provide a "science of phenomena" (phenomen-ology) requires exhibiting a commitment to "sifting out" those implicit and expression "claims" that cannot withstand critical examination from those that, at least provisionally, can gain confirmation based on evidence-based judgments. ${ }^{99}$

At the same, we also need to appreciate the tensions and internal inconsistencies within Husserlian phenomenology itself. These include its partial failure to fully integrate the centrality of physical embodiment to lived experience into methodological self-reflection. Whilst Husserl produced valuable studies of such embodiment, especially in Ideas 11 and Cartesian Meditations, ${ }^{100}$ it is arguable that the radical implications of these for his starting point in self-reflection upon consciousness remained underdeveloped.

Another difficulty lies in the underdeveloped mode of conducting critique that Husserl's largely descriptive approach applies. Other issues concern the problematic status of appeals

\footnotetext{
${ }^{96}$ Husserl, 1964 op cit, 22.

97 Husserl, 1964 op cit, 25-6, 40; Zaner 1970 op cit, 79, 107, 194.

98 Zaner, 1970 op cit, 200.

99 Zaner, 1970 op cit, 113.

${ }^{100}$ Husserl 2010 op cit; Husserl Cartesian Meditations, Tr Dorion Cairns, Martinus NIjhoff, 1960, Fifth Meditation, especially $\$ 44$ (92-99), §§51-56 (112-31). On the latter see James L. Marsh, 'An Inconsistency in Husserl’s Cartesian Meditations,’ The New Scholasticism Volume 53, Issue 4, Autumn 1979: 460-474.
} 
to pre-linguistic lived experience, combined with a recognition by the later Husserl that life-world experience is constituted against a discursive backgrounds of transmitted categories. In addition, there is an undeniable tension between the essentially static quality of phenomenology's structural analysis, and the implications of its recognition of the streaming flux of lived experience, including the experience of inner time consciousness, which entails historical reconstructions of a distinctive form of cultural history. Finally, there is the danger that Husserl's appeal to a science of purified experience involves a classic enlightenment-style "prejudice against prejudice," which is inconsistent with the recognition that a complete suspension of presuppositions is almost certainly impossible. In the field of hate crime, a more nuanced and worked through approach to discriminatory prejudice and its contestation is surely called for, albeit one that refuses to either ontologise or naturalise any particular type of prejudice.

Nevertheless, the point remains that the scientific claims of phenomenology depend on its optimal freedom from taken for granted prejudices and presuppositions as a regulative ideal to which actual studies of hate crime must seek to approximate as far as humanly possible. Such discoveries can only be contingent, context specific and reflexively aware of their own current limits and debts stemming from the influences of a given and always presupposed life-world situation, many of which cannot be fully appreciated or taken into account. ${ }^{101}$ Indeed, the step-by-step analysis progressively uncovering the presence of deep-seated prejudices as constitutive of lived experience, including phenomenological self-reflection, remains a challenging but still unavoidable theme. ${ }^{102}$ Rather than dismiss phenomenology as a position involving a self-negating "prejudice against prejudice" it is

\footnotetext{
101 O'Neil, 1972 op cit, 5.

102 See Harris and Salter, 1994 op cit; Zaner 1970 op cit, 17-18, 29.
} 
more fruitful to develop its critical ethical and policy dimensions that challenge the specific types of prejudicial understandings constitutive of much hate crime, albeit in ways that strive to resolve the contradictions just alluded to. 